\title{
Analysis of Implementation of State Householder State Housing (Case Study at Country Household Storage House of State Class 1 Samarinda)
}

\author{
Marwiah Johansyah ${ }^{1}$ \\ \{Marwiahjo1987@yahoo.com $\left.{ }^{1}\right\}$ \\ Lecturer of FKIP Universitas Mulawarman ${ }^{1}$
}

\begin{abstract}
The purpose of this study is to clearly see the management of state seized goods in Class 1 Samarinda Rupbasan, as well as the dangers that arise in the management of state seized objects in Class 1 Samarinda and PT. settlement efforts. This research is a descriptive type of research and if viewed from the understanding it includes empirical legal research The research approach used in this research is qualitative analysis. Based on the results of the research that has been done, it can show that the implementation of the management of objects regulated in the Regulation of the Minister of Justice of the Republic of Indonesia Number: M.05.UM.01.06 Year 1983. Meanwhile, the implementation guidelines are regulated in the Decree of the Director General of Corrections Number: E2. UM.01.06 of 1986 which has been enhanced by the Decree of the Director General of Corrections Number: E1.35.PK.03.10 of 2002 concerning Implementation Guidance and Technical Guidance of State-Made Goods and State Seized Goods at the State Conspiracy Storage Center. The implementation mechanism for the management of state goods and state booty in Rupbasan includes receipt, registration, registration, maintenance, removal, rescue, security, release and deletion as well as reporting. In the implementation of the management of confiscated materials at the Class 1 Rupbasan Samarinda, there are still problems that fall within the internal and external domains.
\end{abstract}

Keywords: Implementation, Management, Rupbasan.

\section{Introduction}

Indonesia is a legal state. Thus the affirmation of Article 1 Paragraph (3) of the Constitution of the Republic of Indonesia 1945. As a state of law, the state guarantees all citizens at the same time in the law and government, and is obliged to uphold such law and government with no exception. So all the behavior and deeds of Indonesian society must be based on the applicable law, both written law and unwritten law. So that any problems arising relating to violation of law then be resolved by law in effect at that time.

In the Criminal Procedure Code, Indonesia has Law No. 8 of 1981 on Criminal Procedure Code. With the creation of the Criminal Procedure Code (KUHAP), for the first time in Indonesia a complete codification and unification shall be encompassed in the sense of covering all criminal proceedings from the beginning of the investigation to the Supreme Court appeal, even to include the Herziening and the execution of the decision. 
In carrying out its role as procedural law, the Criminal Procedure Code regulates the existence of forcible attempts in the investigation of arrest, detention, searches, seizure and examination of letters. Regarding the seizure according to Article 1 point 16 stated:

"The seizure is a series of investigative measures to take over and or to retain under his control of immovable or immovable, tangible or intangible objects for the sake of proof in investigation, prosecution and judicial proceedings."

In connection with foreclosure, confiscated items may include:

1. Objects or bills of a suspect or defendant wholly or partially derived from a crime or part of proceeds of a criminal offense.

2. Objects that have been used directly to commit a crime or prepare it.

3. Objects used to prevent criminal investigations.

4. Made specifically for committing a crime.

5. And other objects directly related to the crime committed.

The five objects can be used and categorized as evidence and function in the process of examination of a criminal case, so that in the process of obtaining evidence and confiscation and placing the confiscated goods needed a place which is the central storage of all kinds of confiscated goods.

Regarding the storage of state confiscated items as evidence in a criminal case, the Criminal Procedure Code (Criminal Procedure Code) is contained in Article 44 paragraph (1) which reads: "State Confiscated Objects are kept in Storage House of State Treated Objects". In the Samarinda region there is a House of State Confiscated Storage House, but its function and role can not be said maximally, due to the absence of a functional policy which stipulates that the need for Rupbasan in a criminal court proceeding process concerning the storage of evidences which has been used by the general public Rupbasan has not functioned properly with regard to the safeguarding, storing, securing, and saving of confiscated objects. Structurally and functionally, Rupbasan is under the Ministry of Justice environment which will be the storage hub of all sorts of confiscated goods from various agencies. Establishment of Rupbasan is based on Article 44ayat (1) KUHAP and also PP. 27 of 1983 and the Minister of Justice Regulation no. M.05.UM.01.06 Year 1983.

In relation to the so-called RUPBASAN arranged in the Criminal Procedure Code, PP No.27 of 1983 and the Minister of Justice Regulation no. M.05.UM.01.06 In 1983, it was not yet clear on the implementation of the implementation. To clarify the implementation, it is necessary to know how the Mechanism of Implementation of State Seizure and State Confiscated Management in Rupbasan, so that it is then regulated in the Decree of the Director General of Corrections No. E1.35.PK.03.10 of 2002 on the Implementation Guidelines and Technical Guidelines for the Management of State Stamped and State Confiscated Goods in RUPBASAN, as the elaboration of the Regulation of the Minister of Justice no. M.05.UM.01.06 Year 1983.

In order to implement the Management of State Confiscated State and State Confiscated Goods in Rupbasan, it is necessary to have a good cooperation from various related institutions such as Courts, Police and Attorney General as well as other agencies to submit confiscated objects to be stored in Rupbasan its security can be maintained and protected and if in the judicial process the decision to be returned can be returned completely without any defects or damages. According to Anton.M.Moeliono, management is the process of providing supervision on all matters involved in the implementation of policy and achievement of goals (Anton.M.Moeliono, 1998: 534). 
Based on the above considerations the authors want to conduct research in order to find out more in depth about the mechanism of implementation of confiscation of state confiscated objects and spoils of state in Rupbasan and to know the obstacles that arise in the implementation and efforts to solve it.

\section{Research Methods}

In this research method using qualitative descriptive research method. (Sugiyo, 2010: 165), declared descriptive qualitative research is a method conducted with the aim to lift facts, circumstances, variables, and phenomena that occur when research takes place and presents what it is.

Descriptive research can also be defined as research that aims to make a description of the phenomena found, both in the form of risk factors or effects or results. The phenomenon of research results is presented as is, without trying to analyze how and why the phenomenon can occur. (Arikunto, 2002: 44).

Through this type of qualitative description research the author uses the normativeempirical legal approach. This study focuses on legislation in relation to one another and its relevance in practice. And the topics in this study is the problem of optimization of a legal entity, the role of legal institutions or legal institutions, and the implementation of the rule of law in accordance with legislation.

\section{Result and Discussion}

The definition of seizure, formulated in Article 1 of the 16th item of the Criminal Procedure Code, which reads: "seizure is a series of investigative actions to take over and / or keep under the control of immovable or immovable, tangible or intangible objects for the purpose of proof in the investigation, prosecution, and justice (Criminal Procedure Code, Article 1 point 16).

Foreclosure is a legal action in the process of investigation conducted by the investigator to legally control of a good, both movable and immovable goods allegedly closely related to the crime being committed (Hartono, 2010: 182).

A means by a competent authority to temporarily control the goods belonging to a suspect or defendant or not, but deriving from or related to a crime and useful for proof (Darwin Prinst, 2002: 69).

The purpose of seizure, for the sake of "proof", is primarily intended as evidence in court. Most likely without evidence, the case can not be submitted to the court. Therefore, in order for the case to be completed with the evidence, the investigator forecloses to be used as evidence in the investigation, in the prosecution and examination of court proceedings (M.Yahya Harahap, 2007: 265).

By looking at the provisions governing seizure, within the law there are different forms and procedures for foreclosure. Are as follows :

1. Ordinary foreclosure

2. Foreclosure in circumstances necessary and urgent

3. The seizure is caught red-handed

4. Indirect confiscation 


\section{Confiscation of other letters or writings}

The foreclosure action can only be conducted by the investigator with the permission of the local District Chief Justice. In a very urgent circumstance, if the investigator must act immediately and it is impossible to obtain a permit first, without prejudice to the requirement of the permission of the Chief Justice, the investigator may confiscate only the moving object and shall immediately report to the District Court Chief to obtain approval (Bima Priya Santosa, et al, 2010: 12).

In the Minister of Justice Regulation no. M.05.UM.01.06 of 1983 on the Management of State Confiscated Materials and State Confiscated Goods in RUPBASAN, explains the definition of confiscated and confiscated objects of the State, namely:

a. State confiscated items are objects confiscated by an investigator, public prosecutor or an official whose position has the authority to confiscate goods for the purposes of evidence in the judicial process.

b. The spoils of the State are evidences that have obtained permanent legal force, are seized for a State which is subsequently executed by: destroyed, auctioned for the State, submitted to the agency designated for use and submitted in RUPBASAN for the purposes of evidence in another case.

c. The provision of Article 44 of KUHAP stipulates that the storage of confiscated objects is in RUPBASAN. Furthermore, the storage of confiscated items shall be regulated in Government Regulation Number 27 of 1983 concerning the Implementation of the Criminal Procedure Code, Article 27 paragraph (1) that in the RUPBASAN shall be placed items to be kept for the purposes of the evidence in the examination at the level of investigation, prosecution and examination in court including goods which are declared seized based on judge's decision (PP No. 27 year 1983, Article 27 paragraph (1).

In this case, M. Yahya Harahap gives some functions RUPBASAN, namely:

1. Function and responsibility of acceptance

2. Maintenance and security functions

3. The function of expenditure and destruction of seized objects

Factors that affect less optimal task and function RUPBASAN:

1. RUPBASAN officers are still not very good in terms of quality and quantity.

2. Land and buildings and warehouses RUPBASAN not adequate.

3. Limited security equipment.

4. Very minimal maintenance cost.

5. Minimal implementation of Training for RUPBASAN officers.

6. Interest becomes a low RUPBASAN officer.

Efforts to optimize the tasks and functions RUPBASAN can be done as soon as possible without the need to add much burden on the state budget to manage it, that is by adding or expanding Rupbasan building and with the addition of its human resources, but also add the necessary operational costs, either to optimize auction sales activities or destruction of confiscated objects under Article 45 of KUHAP. 


\section{Conclusion}

The definition of seizure, formulated in Article 1 of the 16th item of the Criminal Procedure Code, which reads: "seizure is a series of investigative actions to take over and / or keep under the control of immovable or immovable, tangible or intangible objects for the purpose of proof in the investigation, prosecution, and justice (Criminal Procedure Code, Article 1 point 16).

The type of research used is qualitative description research using normative-empirical law approach. This study focuses on legislation in relation to one another and its relevance in practice. And the topics in this study is the problem of optimization of a legal entity, the role of legal institutions or legal institutions, and the implementation of the rule of law in accordance with legislation.

Constraints that arise in carrying out the tasks and functions of state confiscated objects, especially in Rupbasan Class 1 Samarinda covers internal constraints and external constraints. These constraints include the following:

a. In terms of readiness Rupbasan personnel are still limited human resources (officials / officers) are viewed from the point of quality and quantity.

b. Limitations of facilities and infrastructure concerning buildings / warehouses and budgets in support of the implementation of Rupbasan function.

c. The presumption of law enforcement officials that Rupbasan Surakarta is considered not able to store / manage confiscated objects state.

d. There is no common perception of society towards Rupbasan, especially related institutions.

Efforts to overcome the obstacles that arise in carrying out the tasks and functions of State confiscated objects in Rupbasan Class 1 of Samarinda are as follows:

a. In terms of readiness Rupbasan personnel are still limited human resources (officials / officers) are viewed from the point of quality and quantity. For Rupbasan support personnel now there are 18 people. This is when viewed from the work area and the existing workload of course is still inadequate. Facing such obstacles, Head of Rupbasan has filed an application to the Head of Regional Office of the Department of Justice for the addition of personnel assistance

b. Limitations of facilities and infrastructure related to buildings / warehouses and budgets in support of the implementation of Rupbasan function to overcome the limitations of facilities and infrastructure concerning buildings / warehouses, Head of Rupbasan have applied to the Local Government of Samarinda City in order to cultivate the land in a representative manner. Regarding budget constraints in support of Rupbasan's function, the Head of Rupbasan has submitted an application to the Head of Regional Office of the Department of Justice for additional budget.

c. The presumption of law enforcement officials that Rupbasan Class 1 Samarinda is considered not able to store / manage confiscated objects state. Rupbasan Class 1 Samarinda is still new since it was established in 2003 so that law enforcement officers assume Rupbasan has not been able to store confiscated objects professionally. The obstacle is overcome by the Head of Rupbasan by coordinating with the apparatus or related institutions.

d. There is no common perception of society towards Rupbasan, especially related institutions. 
Poor public image of the management of state confiscated objects and spoils of state, this is because the community is difficult to know how the actual process that occurred after the police as investigators seized / seized the property belonging to the people who are in the hands of the apparatus. Confiscated objects that should be stored in Rupbasan but many of the relevant agencies are still not willing to release the goods and sometimes confiscated objects are used by themselves by relevant agencies without any accountability. To overcome these obstacles, Head of Rupbasan Samarinda held socialization to the public and related institutions through counseling about Rupbasan, in addition Rupbasan also hold MOU with Poltabes.

\section{References}

[1]. Hartono, 2010, Criminal Investigation \& Enforcement, Jakarta: Sinar Grafika Offset.

[2]. Hamzah, Andi, 2005, Indonesian Criminal Procedure Code, Jakarta: Sinar Grafika

[3]. Moeljatno, 1983. Principles of Criminal Law, Rineka Cipta, Jakarta.

[4]. Soekanto, Soerjono. 1986. Introduction to Legal Research. Rineka Cipta. Jakarta\#

[5]. Bima Priya Santosa, 2010. Institute of Criminal Assets Management. Jakarta: Paramadina Public Policy Institute.

[6]. Harahap, Yahya, 2000, Discussion on Problems and Implementation of Criminal Procedure Code, Jakarta: Sinar Grafika.

[7]. Sugiyono, 2010. Qualitative Research Data Analysis. Jakarta: Raja Grafindo Persada

[8]. Setyadi, Sigit, 2016. The Role of Household Storage State Objects in Law Enforcement, Yogyakarta: Janabadra University

[9]. Nasrudin, Edy, 2005. Effectiveness of Management Accounting Information Systems State Assets Management of State Assets, Surakarta: Sebelas Maret University

[10].Niki Citra Puteri Salihah, 2011. Physical Responsibility for Confiscated Materials related to Storage Outside the State House of State Settlement Storage Prior to Decision of the Court, Depok: University of Indonesia. 